\title{
Phylogenetic Position of the Genus Hydrogenobacter
}

\author{
CHRISTIAN PITULLE, ${ }^{1}$ YINQING YANG, ${ }^{1}$ MARCELLO MARCHIANI, ${ }^{2}$ EDWARD R. B. MOORE,${ }^{3}$ \\ JANET L. SIEFERT, ${ }^{1}$ MICHEL ARAGNO, ${ }^{2}$ PETER JURTSHUK, JR., ${ }^{1}$ AND GEORGE E. FOX ${ }^{1 *}$ \\ Department of Biochemical and Biophysical Sciences, University of Houston, Houston, Texas 77204-5934'; \\ Laboratoire de Microbiologie, Institut de Botanique de l'Université de Neuchâtel, CH-2007 Neuchâtel, Switzerland ${ }^{2}$; \\ and Abteilung Mikrobiologie, Gesellschaft für Biotechnologische Forschung, 38124 Braunschweig, Germany ${ }^{3}$
}

\begin{abstract}
The genus Hydrogenobacter consists of extremely thermophilic, obligately chemolithotrophic organisms that exhibit anaerobic anabolism but aerobic catabolism. Preliminary studies of the phylogenetic position of these organisms based on limited 16S ribosomal DNA sequence data suggested that they belong to one of the earliest branching orders of the Bacteria. In this study, the complete $16 \mathrm{~S}$ ribosomal DNA sequences of two type strains, Hydrogenobacter thermophilus TK-6 and Calderobacterium hydrogenophilum Z-829, and another isolate, Hydrogenobacter sp. strain T3, were determined, and the phylogenetic positions of these organisms were examined. Our results revealed that the two type strains are members of a single genus, the genus Hydrogenobacter. Our results also verified the previous conclusion that the Aquifex-Hydrogenobacter complex belongs to a very early branching order, the "Aquificales." Within this order, the relationships among the various organisms are such that only a single family, the "Aquificaceae," can be recognized at this time. Given the early branching point of the "Aquificales," the characteristics of these organisms support the view that the last common ancestor of existing life was thermophilic and suggest that this ancestor may have fixed carbon chemoautotrophically.
\end{abstract}

It has been proposed that aerobic, thermophilic, hydrogenoxidizing, autotrophic bacteria played an important role in the primary production of organic matter on the early earth and that the ancestors of the Bacteria may have been thermophilic $(4,12)$. The increasing attention paid to thermophilic organisms as possible representatives of the earliest forms of life has resulted from the observation that the vast majority of the earliest branching organisms on 16S rRNA-based phylogenetic trees have this phenotype. The discovery of highly thermophilic, aerobic, hydrogen-oxidizing bacteria belonging to the genera Hydrogenobacter and Aquifex in geothermal hot springs was surprising, if one considers the hypothesis that free oxygen appeared only as a consequence of photosystem II. It has been suggested that photosystem II developed much later in evolution, when the mean temperatures on the earth's surface were in the mesobiotic range (5). For this reason, the correct phylogenetic placement of these organisms deserves a thorough and detailed examination.

Among the Bacteria, the Thermotoga lineage was previously thought to be the deepest phylogenetic branch and the most slowly evolving lineage $(1,46,47)$. Interestingly, on the basis of its partial $16 \mathrm{~S}$ rRNA sequence the more recently described highly thermophilic hydrogen-oxidizing organism Aquifex pyrophilus, which was isolated from submarine hydrothermal vents, appeared to represent an even earlier branching event $(12,16)$. With an optimum growth temperature of $95^{\circ} \mathrm{C}$, this organism is among the most thermophilic of the members of the Bacteria that have been described.

On the basis of DNA-DNA hybridization data, the genus Aquifex was determined to be closely related to the genus Hydrogenobacter, whose members are also extremely thermophilic. The hypothesis that the genera Hydrogenobacter and Aquifex are related is also supported by the results of a comparison of 550 nucleotides of the $16 \mathrm{~S}$ rRNAs of Hydrogenobacter thermophilus TK-H and $A$. pyrophilus Kol5a $(12,16)$ and more recently by the observation that $A$. pyrophilus also appears to assimilate $\mathrm{CO}_{2}$ by the reductive citric acid cycle (8).

* Corresponding author. Phone: (713) 743-8363. Fax: (713) 7438351. Electronic mail address: fox@uh.edu.
In addition, the genus Calderobacterium closely resembles the genus Hydrogenobacter in both phenotypic and biochemical properties. The organisms belonging to the "HydrogenobacterCalderobacterium group" are unusual in that (i) they are the only obligate lithoautotrophs among the aerobic hydrogenoxidizing bacteria; (ii) they fix $\mathrm{CO}_{2}$ through the reductive tricarboxylic acid cycle; and (iii) they possess unique cellular components and have a unique cellular organization. These organisms contain a 2-methylthio-1,4 naphthoquinone and cytochrome $c_{522}$ and have very small genomes $\left(1.4 \times 10^{9}\right.$ to 1.6 $\left.\times 10^{9} \mathrm{Da}\right)$, and their major cellular lipids include unusual linear $\mathrm{C}_{18: 0}$ and $\mathrm{C}_{20: 1}$ fatty acids $(4,17-19,27,36,43)$.

Burggraf et al. (12) proposed that the genera Aquifex and Hydrogenobacter belong to a single family, the "Aquificaceae," within the new order "Aquificales." However, in previous studies only 35\% (29) of the Hydrogenobacter 16S rRNA sequence was determined. Furthermore, these studies did not include two almost simultaneously and independently described Hydrogenobacter type strains, $H$. thermophilus TK-6 (22) and Calderobacterium hydrogenophilum Z-829 (24). Although the results of the previous study were highly suggestive, they must be regarded as preliminary.

In this study the previous results were extended by including the two type strains mentioned above, $H$. thermophilus TK-6 and $C$. hydrogenophilum Z-829, and a strain isolated from a geothermal spring in Tuscany, Italy, Hydrogenobacter sp. strain T3 (10). These organisms were compared by performing both a DNA-DNA hybridization analysis and an analysis of the complete 16S rRNA sequences. Our data were used to determine the phylogenetic position of the genus Hydrogenobacter relative to all other members of the Bacteria included on the electronically published ribosomal data base project (RDP) (26) tree.

Species descriptions of the organisms studied. $H$. thermophilus (22) is an obligately chemolithotrophic, hydrogen-oxidizing, thermophilic, microaerophilic species. It exhibits strictly respiratory, aerobic metabolism. $\mathrm{CO}_{2}$ is fixed via the reductive tricarboxylic acid cycle (43). Reduced sulfur compounds can also be used as electron donors $(2,11)$. The optimum temperature for growth is between 70 and $75^{\circ} \mathrm{C}$, and the maximum 
temperature is between 75 and $80^{\circ} \mathrm{C}$. The guanine-plus-cytosine $(\mathrm{G}+\mathrm{C}$ ) content (38 to $44 \mathrm{~mol} \%$ ) is the lowest $\mathrm{G}+\mathrm{C}$ content that has been found so far among the aerobic hydrogen-oxidizing bacteria (6). The cells are gram negative. The type strain is $H$. thermophilus TK-6 (22).

C. hydrogenophilum (24) was isolated from geothermal manifestations in Kamchatka, Russia. The description of this organism is quite similar to that of the genus Hydrogenobacter. The type strain is $C$. hydrogenophilum Z-829 (24). Several strains related to $H$. thermophilus have been isolated from various geothermal sites in Kamchatka (Russia), Italy, Iceland, and Japan $(4,5,10,11,23,27,30)$. Other similar strains have been isolated in the Azores, New Zealand, Indonesia, Greece, Djibouti, and the United States (28). The strains that have been isolated to date form five clear-cut DNA-DNA homology groups, whose members are more or less related by their geographical origins $(4,11,28)$.

\section{MATERIAL AND METHODS}

Organisms. $H$. thermophilus $\mathrm{TK}-6^{\mathrm{T}}$ ( $\mathrm{T}=$ type strain), $H y$ drogenobacter sp. strain $\mathrm{T} 3$, and $C$. hydrogenophilum Z-829 were cultivated in $300-\mathrm{ml}$ portions of the basal mineral medium described by Aragno and Schlegel (6) under an atmosphere consisting of $10 \mathrm{kPa}$ of $\mathrm{CO}_{2}, 5 \mathrm{kPa}$ of $\mathrm{O}_{2}$, and $40 \mathrm{kPa}$ of $\mathrm{H}_{2}$ (partial pressures were measured at room temperature). The atmosphere used contained $10 \% \mathrm{CO}_{2}, 5 \% \mathrm{O}_{2}$, and $70 \%$ $\mathrm{H}_{2}$.

Determination of DNA base composition and DNA-DNA hybridization. Cells ( 2 g/liter) were collected at the late log phase, resuspended and washed in $15 \mathrm{ml}$ of TE buffer $(10 \mathrm{mM}$ Tris-HCl, 1 mM EDTA; pH 7.2), and sonicated with a Branson model 450 sonicator for $1 \mathrm{~min}$ at 50 to $60 \mathrm{~W}$ in $7.5 \mathrm{M}$ urea-125 $\mathrm{mM} \mathrm{NaH} \mathrm{PO}_{4}-125 \mathrm{mM} \mathrm{Na} \mathrm{HPO}_{4}(\mathrm{pH} \mathrm{7.5).} \mathrm{DNAs} \mathrm{were}$ isolated and $\mathrm{G}+\mathrm{C}$ contents were determined as described by Jenni et al. (20). DNA-DNA hybridization was performed by the thermal renaturation rate method (31), using a Gilford model 2600 spectrophotometer equipped with a model 2527 thermoprogrammer. Escherichia coli B DNA was used as the reference DNA. For calculations we used the formula of Owen and Hill (35).

Oligonucleotide synthesis. PCR primers and sequencing primers were synthesized with a Biosearch model 8600 DNA synthesizer by the phosphoramidite method $(7,45)$.

Isolation of genomic DNA and PCR amplification of 16S ribosomal DNA (rDNA). Portions $(100 \mu \mathrm{g})$ of cells were resuspended in $500 \mu \mathrm{l}$ of $0.15 \mathrm{M} \mathrm{NaCl}-0.1 \mathrm{M}$ EDTA $(\mathrm{pH} 8)$ and treated with $200 \mu \mathrm{g}$ of lysozyme and $50 \mu \mathrm{g}$ of proteinase $\mathrm{K}$ at $37^{\circ} \mathrm{C}$ for $45 \mathrm{~min}$. Sodium dodecyl sulfate was added to a concentration of $1.8 \%(\mathrm{vol} / \mathrm{vol})$, and the temperature was increased to $60^{\circ} \mathrm{C}$ for $10 \mathrm{~min}$. The reaction mixture was cooled to room temperature and gently mixed with $1.2 \mathrm{M}$ sodium acetate $(\mathrm{pH} 7)$, and the DNA was extracted with 1 volume of chloroform-isoamyl alcohol (24:1, vol/vol). After the aqueous phase was separated by centrifugation at $13,000 \times g$ for $5 \mathrm{~min}$ at $4^{\circ} \mathrm{C}$, the DNA was precipitated by adding 2 volumes of ethanol, incubating the preparation for $10 \mathrm{~min}$ on dry ice, and then centrifuging the preparation at $13,000 \times g$ for $15 \mathrm{~min}$ at $4^{\circ} \mathrm{C}$. The dry pellet was redissolved in $100 \mu \mathrm{l}$ of TE buffer $(\mathrm{pH}$ 8) containing $10 \mu \mathrm{g}$ of RNase A. The solution was incubated at $37^{\circ} \mathrm{C}$ for $30 \mathrm{~min}$. Following repeated extraction with TE buffer-saturated phenol, phenol-chloroform (1:1, vol/vol), and chloroform, the DNA was precipitated by adding sodium acetate to a concentration of $0.3 \mathrm{M}$ and 2 volumes of ethanol as described above. The dry DNA pellet was redissolved in TE buffer $(\mathrm{pH} 8)$ at a concentration of $0.5 \mathrm{mg} / \mathrm{ml}$.
Each PCR mixture contained $8 \mathrm{U}$ of Taq DNA polymerase (Promega), $100 \mathrm{ng}$ of forward primer A (5'-CCGAATTCGTC GACAAGAGTTTGATCCTGGCTCAG-3'; the SalI restriction site $[21,42]$ is in boldface type; positions 9 to 27 [E. coll numbering system] are underlined), $100 \mathrm{ng}$ of reverse primer $\mathrm{B}$ (5'-CCCGGGATCCAAGCTTAGAAAGGAGGTGATCCA$3^{\prime}$; the HindIII restriction site [42] is in boldface type; the underlined region is complementary to positions 1544 to 1528 [E. coli numbering system]), and $500 \mathrm{ng}$ of genomic DNA. The reaction volume was $100 \mu \mathrm{l}$, and the reaction mixture was overlaid with sterile mineral oil as described by Saiki (37). The PCR was performed with a DNA thermal cycler (Perkin Elmer Cetus) under the following conditions: $5 \mathrm{~min}$ at $94^{\circ} \mathrm{C} ; 5$ cycles consisting of $1 \mathrm{~min}$ at $94^{\circ} \mathrm{C}, 2 \mathrm{~min}$ at $37^{\circ} \mathrm{C}$, and $2 \mathrm{~min}$ at $65^{\circ} \mathrm{C}$; 20 cycles consisting of $1 \mathrm{~min}$ at $94^{\circ} \mathrm{C}, 2 \mathrm{~min}$ at $42^{\circ} \mathrm{C}$, and $2 \mathrm{~min}$ at $72^{\circ} \mathrm{C}$; and $8 \mathrm{~min}$ at $72^{\circ} \mathrm{C}$.

For direct sequencing of PCR-amplified 16S rDNA, PCR amplification was performed with forward primer A2 (positions 8 to 27 [E. coli numbering system]) and reverse primer $\mathrm{B} 2$ (5'-AAGGAGGTGWTCCAGCC-3'; complementary to positions 1547 to 1528 [E. coli numbering system]). Each PCR mixture contained $10 \mathrm{mM}$ Tris- $\mathrm{HCl}(\mathrm{pH} 8.3), 1.5 \mathrm{mM} \mathrm{MgCl}_{2}$, $50 \mathrm{mM} \mathrm{KCl}, 100 \mu \mathrm{g}$ of gelatin, $2 \%$ (vol/vol) formamide, each of the four deoxynucleoside triphosphates at a concentration of $200 \mu \mathrm{M}$, each of the two primers at a concentration of $0.6 \mu \mathrm{M}, 1.0 \mu \mathrm{g}$ of genomic DNA, and 2.5 $\mathrm{U}$ of Taq DNA polymerase (Promega). A total of 30 cycles having the following profile were used: $1 \mathrm{~min}$ at $94^{\circ} \mathrm{C}, 1 \mathrm{~min}$ at $50^{\circ} \mathrm{C}$, and $2 \mathrm{~min}$ at $72^{\circ} \mathrm{C}$. This was followed by a final elongation step at $72^{\circ} \mathrm{C}$ for $10 \mathrm{~min}$. The amplified DNA was extracted with chloroformisoamyl alcohol $(24: 1$, vol/vol $)$ and purified with a Centricon100 microconcentrator (Amicon).

Cloning of the PCR-amplified 16S rDNA. Portions $(1 \mu \mathrm{g})$ of the PCR fragments were digested in $100 \mu \mathrm{l}$ of $1 \times$ buffer D (Promega) containing $12 \mathrm{U}$ of HindIII (Promega) and $12 \mathrm{U}$ of Sall (Promega) at $37^{\circ} \mathrm{C}$ for $4 \mathrm{~h}$. The digested PCR fragments were separated by low-melting-temperature agarose gel electrophoresis $(0.7 \%$ agarose $)$. The appropriate region of each gel was excised, and the DNA was recovered as described by Sambrook et al. (40). Samples $(5 \mu \mathrm{g})$ of plasmid puC19 were digested and purified in the same way.

Ligation was performed by using bacteriophage T4 DNA ligase (United States Biochemical Corp.) and the protocols recommended by the manufacturer.

Transformation of $E$. coli JM109 and plasmid isolation. Preparation and electroporation of cells were performed as described previously $(13,38,44)$ by using $100 \mathrm{ng}$ of puC19 per $50 \mu \mathrm{l}$ of cell suspension. Recombinants were selected on Luria-Bertani medium plates containing ampicillin, as well as X-Gal (5-bromo-4-chloro-3-indolyl- $\beta$-D-galactopyranoside) and IPTG (isopropyl- $\beta$-D-thiogalactopyranoside) for blue and white color screening, respectively (39). Plasmids were isolated from positive clones as described by Birnboim and Doly (9).

Sequencing reaction. Double-stranded cloned 16S rDNAs were sequenced by the dideoxy chain termination method (41), using Sequenase version 2.0 (United States Biochemical Corp.) according to the procedures recommended by the manufacturer. The internal $\alpha^{-35}$-labeled DNA fragments were separated by electrophoresis on $60-\mathrm{cm}$-long wedgeshaped $(0.2-$ to $0.6-\mathrm{mm})$ denaturing $(7 \mathrm{M}$ urea) $6 \%$ polyacrylamide gels at $1,750 \mathrm{~V}$ (constant voltage). The following forward sequencing primers were used (positions according to the $E$. coli numbering system): universal M13 primer (-40) (5'-GTTTTCCCAGTCACGAC-3'), I (positions 109 to 123; $5^{\prime}$-CAGGGTGAGTAACAC-3'), II (positions 323 to 337; 5'-TGAGACACGGCCCAC-3'), III (positions 519 to 536; 
5'-CAGCKGCCGCGGTAATAC-3') (25), IV (positions 690 to $704 ; 5^{\prime}$-GGTGAAATGCGTAGA-3'), $\mathrm{V}$ (positions 786 to 803; 5'-GATTAGATACCCTGGTA-3'), VI (positions 814 to 829; 5'-TAAACCATGGGCGCTAG-3'), and VII (positions 1392 to 1406; 5'-ACGGGCGGTGTCTRG-3') (25). The following reverse sequencing primers were used (complementary to the positions indicated [ $E$. coli numbering system]): I- $r$ (positions 109 to 123 ; 5'-GTGTTACTCACCCGT-3'), III-r (positions 519 to 536; 5'-GTATTACCGCGGCKGCTG-3') (25), IV-r (positions 690 to 704; 5'-TCTACGCATTTCACC$3^{\prime}$ ), V-r (positions 786 to 803; 5'-CTACCAGGGTATCTA ATC-3'), and M13-reverse (5'-TTCACAGGAAACAG-3'). Both strands of the cloned 16S rDNAs from at least two clones were sequenced.

Regions containing areas of sequence uncertainty were reexamined by directly sequencing the PCR products with an Applied Biosystems model 373A automated DNA sequencer, using standard protocols for Taq DNA polymerase-initiated, cycle sequencing reactions with fluorescently labeled dideoxynucleoside triphosphates as described by the supplier. The following forward sequencing primers were used (positions according to the $E$. coli numbering system): $16 \mathrm{~F} 530$ (positions 515 to 530; 5'-GTGCCAGCAGCCGCGG-3'), 16F946 (positions 930 to 946; 5'-CCCGCACAAGCGGT GGA-3'), 16F1103 (positions 1083 to 1103 ; 5'-TGTTGGGT TAAGTCCCGCAAC- $3^{\prime}$ ), and $16 \mathrm{~F} 1238$ (positions 1221 to 1238; 5'-GGCKWCACACGTGMTACA-3') (25). The following reverse sequencing primers were used (complementary to the positions indicated [E. coli numbering system]): 16R343 (positions 343 to 358 ; 5'-ACTGCTGCCTCCCGTA-3'), 16R515 (positions 515 to 533; 5'-TTACCGCGGCTGCTG GCAC-3'), 16R1087 (positions 1087 to 1106; 5'-CTCGTT GCGGGACTTAACCC-3'), and 16R1389 (positions 1389 to 1406; 5'-ACGGCGGTGTGTACAAG-3').

Sequence data analysis and tree construction. Sequence data were entered into a Micro-Vax II computer (Digital Equipment Corp., Maynard Mass.) file containing previously determined aligned 16S rRNA sequences obtained from the RDP (26), using the multiple sequence alignment editor SEQEDT (32). Alignment was based on primary sequence and general conservation of the secondary structure of the $16 \mathrm{~S}$ rRNA and was performed manually. This file of $16 \mathrm{~S}$ rRNA sequences consisted of a subset of the sequences obtained from the RDP that contained 26 of the organisms most closely related to the genera Aquifex and Thermotoga, as well as Haloferax volcanii DS-2, which was used as an outgroup. Because of the availability of the RDP dendrogram of prokaryotic organisms, which was constructed by using the fastDNAml program $(14,26,33)$, we used a similar approach to analyze our sequence data. In effect, this resulted in a recreation of the existing RDP tree, and our tree differed only in the accurate phylogenetic placement of the three additional species used in our study.

Nucleotide sequence accession numbers. The sequences determined in this study have been deposited in the European Molecular Biology Laboratory (EMBL) database under accession numbers Z30214 (H. thermophilus TK-6 ${ }^{\mathrm{T}}$ ), Z30242 (C. hydrogenophilum Z-829 ${ }^{\mathrm{T}}$ ), and Z30189 (Hydrogenobacter sp. strain T3).

\section{RESULTS AND DISCUSSION}

A total of 40 strains belonging to the genus Hydrogenobacter have been isolated to date. The striking phenotypic similarities of these organisms prevent differentiation of more than one species (4). However, as described previously $(4,10)$, the different isolates form five distinct DNA-DNA homology groups, which reflect the geographic origins of the strains. Groups 1 and 2 contain isolates from Italy, including Hydrogenobacter sp. strain T3. Group 3 contains isolates from Iceland. The two Japanese strains, $H$. thermophilus TK- $6^{\mathrm{T}}$ and TK-H, form group 4. The isolates from Kamchatka, including type strain C. hydrogenophilum Z-829, are members of group 5. The DNA-DNA homology values for the three strains investigated in this study are $15 \%$ for $C$. hydrogenophilum Z-829 and $H$. thermophilus TK- $6^{\mathrm{T}}, 0 \%$ for $C$. hydrogenophilum $\mathrm{Z}-829^{\mathrm{T}}$ and Hydrogenobacter sp. strain T3, and $14 \%$ for $H$. thermophilus TK $-6^{\mathrm{T}}$ and Hydrogenobacter sp. strain T3.

The $\mathrm{G}+\mathrm{C}$ contents are $38.3 \mathrm{~mol} \%$ (43 mol\% [22]) for $H$. thermophilus TK-6 ${ }^{\mathrm{T}}, 37.5 \mathrm{~mol} \%$ (39 to $41 \mathrm{~mol} \%$ [24]) for $C$. hydrogenophilum Z-829 ${ }^{\mathrm{T}}$, and $39.9 \mathrm{~mol} \%$ for Hydrogenobacter sp. strain T3. The slight differences between our values and the values determined in previous studies $(22,24)$ probably reflect the different methods used to determine $\mathrm{G}+\mathrm{C}$ contents.

The phenotypic characteristics of $H$. thermophilus $\mathrm{TK}-6^{\mathrm{T}}$ and C. hydrogenophilum $\mathrm{Z}-829^{\mathrm{T}}$ are very similar $(4,22,24)$, and it has been proposed that these strains should be included in a single genus, the genus Hydrogenobacter (4). The level of $16 \mathrm{~S}$ rRNA sequence similarity between $H$. thermophilus TK- $6^{\mathrm{T}}$ and C. hydrogenophilum Z-829 ${ }^{\mathrm{T}}$ which we observed (98\%) (Table 1) convincingly supports this proposal. The genus name $H y$ drogenobacter has priority over the genus name Calderobacterium because the original description of the genus Hydrogenobacter (22) was published in the International Journal of Systematic Bacteriology (22) before the name Calderobacterium was validated (3).

Previous studies of the phylogenetic position of the genus Hydrogenobacter included limited sequence information (29) obtained from one isolate and did not include either of the two proposed type strains, $H$. thermophilus TK-6 and $C$. hydrogenophilum Z-829. The important phylogenetic position of these organisms necessitated the more extensive analysis described in this paper. In order to determine the correct phylogenetic position of the two type strains, as well as the position of Hydrogenobacter sp. strain T3, the total 16S rDNA genes were sequenced and analyzed.

Uncertainties in 16S rDNA sequence data can arise because of sequencing errors, amplification errors, and the possibility of microheterogeneity (15). To minimize such errors, we examined both strands of the $16 \mathrm{~S}$ rDNAs from at least two different clones. If there were still uncertainties, the same area was reexamined by directly sequencing the PCR products. When we reported the sequences to the EMBL, the letter $\mathrm{N}$ was used to indicate uncertain positions and occasional positions at which the different methods used gave different results. Although this designation was used primarily to indicate uncertainties in base identity, it also could reflect uncertainties concerning the numbers of bases actually present. For example, this is the case in the first variable region (near $E$. coli sequence position 60) where the sequencing gels obtained from all three strains exhibited serious band compression.

With two notable exceptions, the results obtained with the manual and automated methods were in excellent agreement. The first exception, $E$. coli positions 875 to 883 , appeared to be a long stretch of $\mathrm{C}$ residues on the manual gels, whereas the automated method revealed in addition two $G$ residues in precisely the positions expected on the basis of known secondary-structure features; the latter sequence for this region was therefore reported. In the second exception, $E$. coli positions 1030 to 1033, manual sequencing gave -GGGACAAUC- in all three organisms, whereas the automated method gave -GGACGGAAUC-. Secondary-structure considerations did 


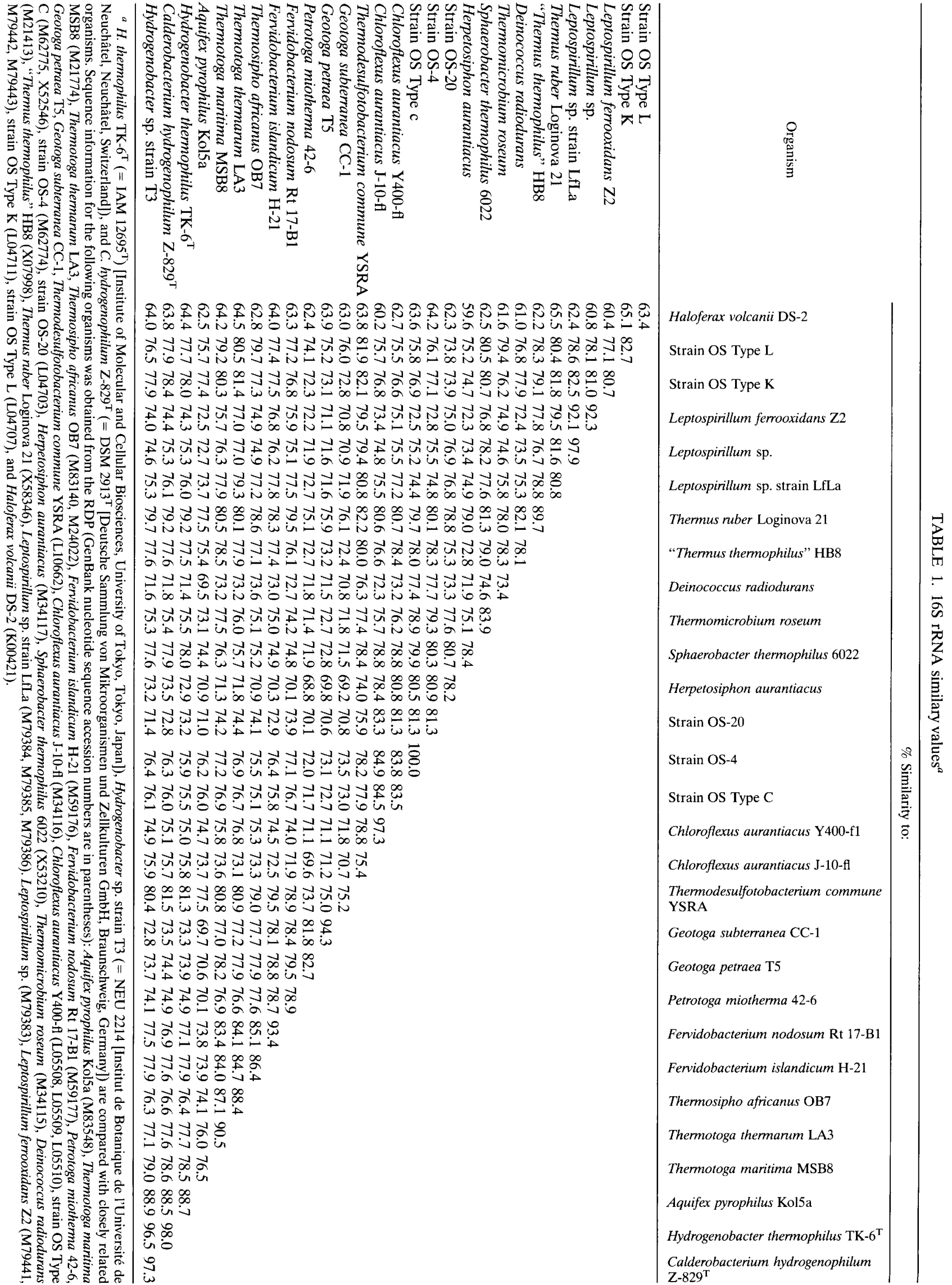




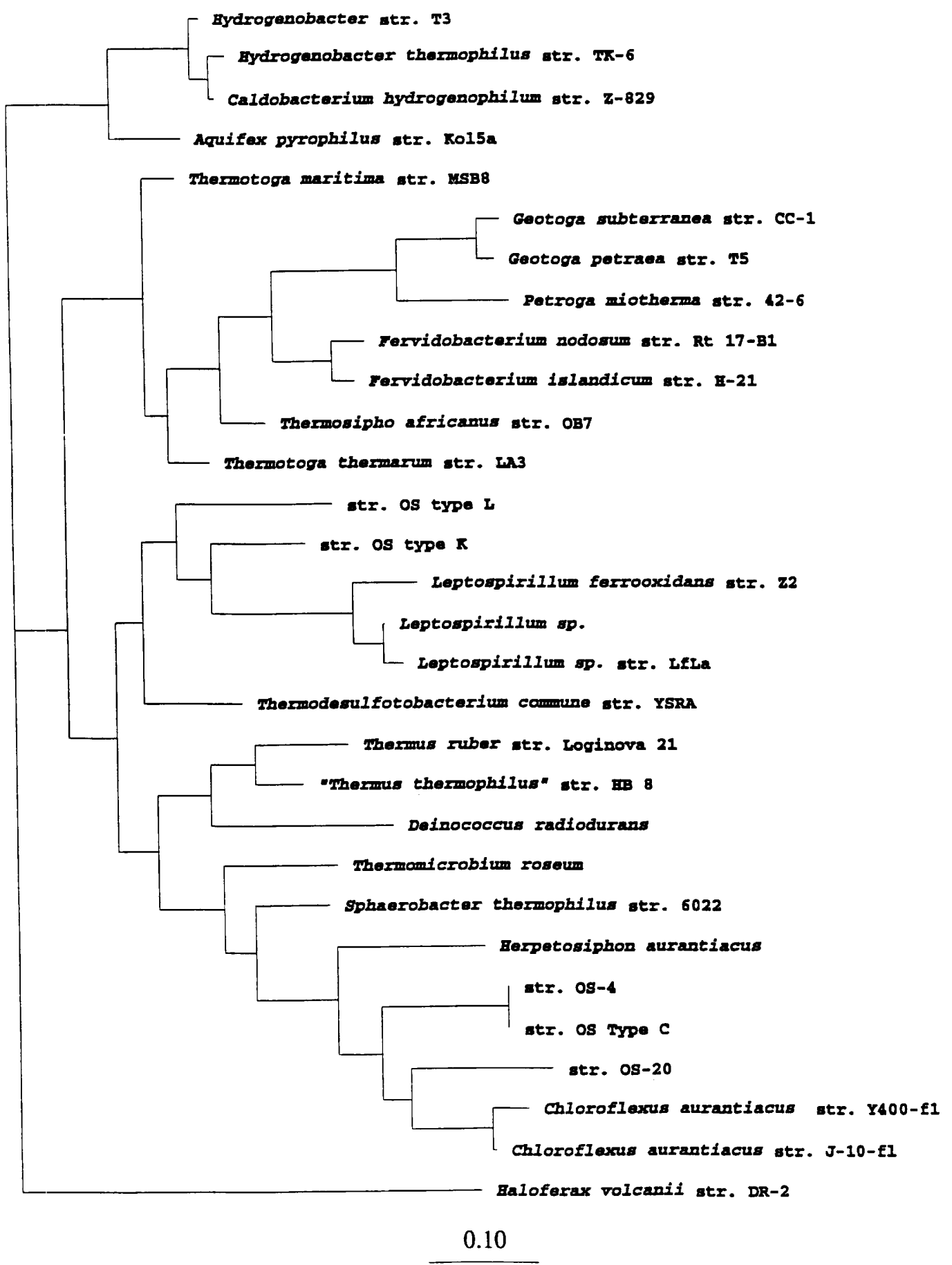

FIG. 1. Phylogenetic tree derived from a maximum-likelihood analysis of the small-subunit rRNA sequences of 27 organisms obtained from the RDP (26) and the three strains used in this study, H. thermophilus TK-6 ${ }^{\mathrm{T}}$, Hydrogenobacter sp. strain T3, and C. hydrogenophilum Z-829 . The archaebacterium Haloferax volcanii was chosen as an outgroup on the basis of the rooting inferred from the universal tree available from the RDP (26). The organisms in the tree are the same strains that are shown in Table 1 . The distance scale indicates the expected number of changes per sequence position for those positions that change at the median rate (34). str., strain

not resolve this ambiguity, and the relevant positions were thus reported as unknown.

Initially, the new sequences were examined in the context of a wide selection of prokaryotic organisms in order to determine the general phylogenetic position of the organisms studied. Trees based on both distance methods and DNA parsimony analysis were used, and these trees exhibited identical branching patterns for the pertinent organisms when they were compared with the tree produced by the fastDNAml algorithm used to construct the RDP tree (14) for Bacteria. Figure 1 shows that the Hydrogenobacter cluster is located among the lower branches of the phylogenetic tree containing 
the known Bacteria. The hydrogenobacter cluster in fact appears to be the most deeply branching lineage, below the Thermotogales lineage and the other thermophilic species that dominate this area of the tree. The close relationship with the genus Aquifex proposed by Burggraf et al. (12) is also supported.

The levels of $16 \mathrm{~S}$ rRNA sequence similarity ranging from 88.5 to $88.9 \%$ between the three strains investigated in this study and $A$. pyrophilus Kol5a also confirm that the genus Aquifex and the genus Hydrogenobacter are closely related and support the proposals that the Aquifex-Hydrogenobacter complex should be placed in the new order "Aquificales" and that the genera Aquifex and Hydrogenobacter belong to the same family, the "Aquificaceae" (12).

With these new results, the early branching position of the Aquificaceae can now be regarded as established, and the evolutionary significance of this conclusion must be considered. Given the phenotypic characteristics of the known members of the order "Aquificales," it appears that the hypothesis that the common ancestor of modern organisms was thermophilic (1) has been strengthened. In addition, despite the partially aerobic character of members of the genus Hydrogenobacter, it is now necessary to seriously consider the possibility that early organisms obtained most of their organic matter by chemoautotrophic carbon fixation rather than from either a residual carbonaceous soup or an ongoing abiotic production system. This view is entirely consistent with and strengthened by the fact that the thermophilic archaean Thermoproteus neutrophilus has been shown to also use the reductive citric acid cycle for autotrophic assimilation of $\mathrm{CO}_{2}(8)$.

The aerobic catabolism of members of the genus Hydrogenobacter is of course problematic given the early branching position of these organisms. If aerobic catabolism was in fact used by ancient hydrogenobacters, then this implies that there was a source of oxygen other than photosystem II available at that time or that photosystem II is older than the best phylogenetic trees currently available suggest. Alternatively, the original terminal electron acceptor used by the ancestral hydrogenobacters might not have been oxygen. If this is true, the ability of modern hydrogenobacters to use oxygen was acquired after the appearance of the cyanobacteria and the consequent buildup of atmospheric oxygen.

\section{ACKNOWLEDGMENTS}

We thank our systems manager, Michael Rice, for continuous monitoring and maintenance of our computing facilities.

This work was partly supported by DFG postdoctoral fellowship Pi 252/1-1 (to C.P.), by NASA grant NAGW-2108 (to G.E.F.), and by Swiss National Science Foundation grant 31-28597.90. Some of the equipment used in this project was purchased with funds provided by NSF grant BIR-9109294.

\section{REFERENCES}

1. Achenbach-Richter, L., R. Gupta, K. O. Stetter, and C. R. Woese. 1987. Were the original eubacteria thermophiles? Syst. Appl. Microbiol. 9:34-39.

2. Alfredson, G. A., A. Ingason, and J. K. Kristjansson. 1986. Growth of thermophilic, obligately autotrophic hydrogen-oxidizing bacteria on thiosulfate. Lett. Appl. Microbiol. 2:21-24.

3. Anonymous. 1984. Validation of the publication of new names and new combinations previously effectively published outside the IJSB. List no. 14. Int. J. Syst. Bacteriol. 34:270-271.

4. Aragno, M. 1992. Thermophilic, aerobic hydrogen-oxidizing (Knallgas) bacteria, p. 3917-3933. In A. Balows, H. G. Trüper, M. Dworkin, W. Harder, and K. H. Schleifer (ed.), The prokaryotes. A handbook on the biology of bacteria, 2nd ed. Springer Verlag, New York.
5. Aragno, M. 1992. Aerobic, chemolithoautotrophic, thermophilic bacteria, p. 77-103. In J. K. Kristjansson (ed.), Thermophilic bacteria. CRC Press, Inc., Boca Raton, Fla.

6. Aragno, M., and H. G. Schlegel. 1992. The mesophilic hydrogenoxidizing (Knallgas) bacteria, p. 344-384. In A. Balows, H. G. Trüper, M. Dworkin, W. Harder, and K. H. Schleifer (ed.), The Prokaryotes. A handbook on the biology of bacteria, 2nd ed. Springer Verlag, New York.

7. Beaucage, S. L., and M. H. Caruthers. 1981. Deoxynucleoside phosphoramidites: a new class of key intermediates for deoxypolynucleotide synthesis. Tetrahedron Lett. 22:1859-1862.

8. Beh, M., G. Strauss, R. Huber, K. O. Stetter, and G. Fuchs. 1993. Enzymes of the reductive citric acid cycle in the autotrophic eubacterium Aquifex pyrophilus and in the archaebacterium Thermoproteus neutrophilus. Arch. Microbiol. 160:306-311.

9. Birnboim, H. C., and J. Doly. 1979. A rapid alkaline extraction procedure for screening recombinant plasmid DNA. Nucleic Acids Res. 7:1513-1523.

10. Bonjour, F. 1988. Ph.D. thesis. University of Neuchâtel, Neuchâtel, Switzerland.

11. Bonjour, F., and M. Aragno. 1986. Growth of thermophilic obligatorily chemolithoautotrophic hydrogen-oxidizing bacteria related to Hydrogenobacter with thiosulfate and elemental sulfur as electron and energy source. FEMS Microbiol. Lett. 35:11-15.

12. Burggraf, S., G. J. Olsen, K. O. Stetter, and C. R. Woese. 1992. A phylogenetic analysis of Aquifex pyrophilus. Syst. Appl. Microbiol. 15:352-356.

13. Calvin, N. M., and P. C. Hanawalt. 1988. High-efficiency transformation of bacterial cells by electroporation. J. Bacteriol. 170:27962801.

14. Felsenstein, J. 1991. PHYLIP (phylogeny inference package), version 3.5. University of Washington, Seattle.

15. Fox, G. E., J. D. Wisotzkey, and P. J. Jurtshuk, Jr. 1992. How close is close: 16S rRNA sequence identity may not be sufficient to guarantee species identity. Int. J. Syst. Bacteriol. 42:166-170.

16. Huber, R., T. Wilharm, D. Huber, A. Trincone, S. Burggraf, H. König, R. Rachel, I. Rockinger, H. Fricke, and K. O. Stetter. 1992. Aquifex pyrophilus gen. nov. sp. nov., represents a novel group of marine hyperthermophilic hydrogen-oxidizing bacteria. Syst. Appl. Microbiol. 15:340-351.

17. Igarashi, Y., and T. Kodama. 1990. Hydrogenobacter thermophilus: its unusual physiological properties and phylogenetic position in the microbial world. FEMS Microbiol. Lett. 87:403-406.

18. Ishii, M., Y. Igarashi, and T. Kodama. 1987. Purification and some properties of cytochrome $\mathrm{c}_{552}$ from Hydrogenobacter thermophilus. Agric. Biol. Chem. 51:1695-1697.

19. Ishii, M., T. Kawasumi, Y. Igarashi, T. Kodama, and Y. Minoda. 1983. 2-Methylthio-1,4-naphthoquinone, a new quinone from an extremely thermophilic hydrogen bacterium. Agric. Biol. Chem. 47:167-170.

20. Jenni, B., M. Aragno, and J. K. W. Wiegel. 1987. Numerical analysis and DNA-DNA hybridization studies on Xanthobacter and emendation of Xanthobacter flavus. Syst. Appl. Microbiol. 9:247-253.

21. Jung, V., S. B. Pestka, and S. Pestka. 1990. Efficient cloning of PCR generated DNA containing terminal restriction endonuclease recognition sites. Nucleic Acids Res. 18:6156.

22. Kawasumi, T., Y. Igarashi, T. Kodama, and Y. Minoda. 1984. Hydrogenobacter thermophilus gen. nov., sp. nov., an extremely thermophilic, aerobic, hydrogen-oxidizing bacterium. Int. J. Syst. Bacteriol. 34:5-10.

23. Kristjansson, J., A. Ingason, and G. A. Alfredsson. 1985. Isolation of thermophilic autotrophic hydrogen-oxidizing bacteria, similar to Hydrogenobacter thermophilus, from icelandic hot springs. Arch. Microbiol. 140:321-325.

24. Kryukov, V. R., N. D. Savel'eva, and M. A. Pusheva. 1983. Calderobacterium hydrogenophilum gen. et sp. nov., an extremely thermophilic hydrogen bacterium and its hydrogenase activity. Microbiology (Engl. Transl, Mikrobiologiya) 52:611-618.

25. Lane, D. J., B. Pace, G. J. Olsen, D. A. Stahl, M. L. Sogin, and N. R. Pace. 1985. Rapid determination of 16 S ribosomal RNA sequences for phylogenetic analyses. Proc. Natl. Acad. Sci. USA 82:6955-6959. 
26. Larsen, N., G. J. Olsen, B. L. Maidak, M. J. McCaughey, R. Overbeek, T. J. Macke, T. L. Marsh, and C. R. Woese. 1993. The ribosomal database project. Nucleic Acids Res. 21:3021-3023.

27. Lysenko, A. M., N. D. Savel'eva, and V. R. Kryukov. 1985. Some peculiarities of the reassociation of DNA of extremely thermophilic hydrogen bacteria. Biochemistry 50:1090-1094.

28. Marchiani, M. (Université de Neuchâtel). 1993. Personal communication.

29. Murray, R. G. E., D. J. Brenner, R. R. Colwell, P. De Vos, M. Goodfellow, P. A. D. Grimont, N. Pfennig, E. Stackebrandt, and G. A. Zavarzin. 1990. Report of the Ad Hoc Committee on Approaches to Taxonomy within the Proteobacteria. Int. J. Syst. Bacteriol. 40:213-215.

30. Nishihara, H., Y. Igarashi, and T. Kodama. 1990. A new isolate of Hydrogenobacter, an obligately chemolithoautotrophic, thermophilic, halophilic and aerobic hydrogen-oxidizing bacterium from seaside saline hot springs. Arch. Microbiol. 153:294-298.

31. Norgard, M. V., and P. F. Bartell. 1978. An accelerated spectrophotometric micro-procedure for the analysis of DNA-DNA hybridization in free solution. Gilford Res. Rev. 3:1-5.

32. Olsen, G. J. 1992. User guide for the multiple sequence alignment editor SEQEDT. Department of Microbiology, University of Illinois, Urbana.

33. Olsen, G. J. 1993. User guide for fastDNAml 1.0. Department of Microbiology, University of Illinois, Urbana.

34. Olsen, G. J., C. R. Woese, and R. Overbeek. 1994. The winds of (evolutionary) change: breathing new life into microbiology. J. Bacteriol. 176:1-6.

35. Owen, R. J., and L. R. Hill. 1979. The estimation of base compositions, base pairing and genome sizes of bacterial deoxyribonucleic acids, p. 277-296. In F. A. Skinner (ed.), Identification methods for microbiologists, 2nd ed. Academic Press, London.

36. Pusheva, M. A., A. P. Sukhikh, N. P. Borodulina, and N. D. Savel'eva. 1988. Characteristics of cytochromes of the extreme thermophilic obligate autotrophic hydrogen bacterium Calderobacterium hydrogenophilum. Microbiology (Engl. Transl. Mikrobiologiya) 49:572-576.

37. Saiki, R. K. 1990. Amplification of genomic DNA, p. 13-27. In
M. A. Innis, D. H. Gelfand, J. J. Sninsky, and T. J. White (ed.), PCR protocols: a guide to methods and applications. Academic Press, New York.

38. Sambrook, J., E. F. Fritsch, and T. Maniatis. 1989. Molecular cloning: a laboratory manual, 2nd ed., p. 1.75. Cold Spring Harbor Laboratory, Cold Spring Harbor, N.Y.

39. Sambrook, J., E. F. Fritsch, and T. Maniatis. 1989. Molecular cloning: a laboratory manual, 2nd ed., p. 1.85-1.86. Cold Spring Harbor Laboratory, Cold Spring Harbor, N.Y.

40. Sambrook, J., E. F. Fritsch, and T. Maniatis. 1989. Molecular cloning: a laboratory manual, 2nd ed., p. 6.30-6.31. Cold Spring Harbor Laboratory, Cold Spring Harbor, N.Y.

41. Sanger, F., S. Nicklen, and A. R. Coulsen. 1977. DNA sequencing with chain terminating inhibitors. Proc. Natl. Acad. Sci. USA 74:5463-5467.

42. Scharf, S. J. 1990. Cloning with PCR, p. 84-91. In M. A. Innis, D. H. Gelfand, J. T. Sminsky, and T. J. White (ed.), PCR protocols: a guide to methods and applications. Academic Press, London.

43. Shiba, H., T. Kawasumi, Y. Igarashi, T. Kodama, and Y. Minoda. 1985. The $\mathrm{CO}_{2}$ assimilation via the reductive tricarboxylic acid cycle in an obligately autotrophic aerobic hydrogen-oxidizing bacterium, Hydrogenobacter thermophilus. Arch. Microbiol. 141: 198-203.

44. Shivarova, N., W. Förster, H. E. Jacob, and R. Grigorava. 1983. Microbiological implications of electric field effects. VII. Stimulation of plasmid transformation of Bacillus cereus protoplasts. Z. Allg. Mikrobiol. 23:595-599.

45. Sinha, N. D., J. Biernat, J. McManus, and H. Köster. 1984. Polymer support oligonucleotide synthesis XVIII: Use of $\beta$-cyanoethyl-N,N-dialkylamino-/ $\mathrm{N}$-morpholino phosphoramidite of deoxynucleosides for the synthesis of DNA fragments simplifying deprotection and isolation of the final product. Nucleic Acids Res. 12:4539-4557.

46. Woese, C. R. 1987. Bacterial evolution. Microbial Rev. 51:221-271.

47. Woese, C. R., O. Kandler, and M. Wheelis. 1990. Towards a natural system of organisms: proposal for the domains Archae, Bacteria, and Eucarya. Proc. Natl. Acad. Sci. USA 87:4576-4579. 